\title{
Modelowanie systemów autonomicznych i optymalizacja ich sposobów na przetrwanie
}

Cybernetyka rozważa problemy naukowe, posługując się modelami rzeczywistości zwanymi systemami, z zastrzeżeniami, że nie wszystkie aspekty rzeczywistości da się przenieść na model i że niektóre właściwości modelu nie są odzwierciedleniem rzeczywistości. Marian Mazur wprowadził model odzwierciedlający działania wszystkich systemów żywych i nazwał go systemem autonomicznym. ${ }^{1}$ Przy użyciu uogólnienia takiego systemu można rozwijać ilościowe aspekty łączenia i optymalizacji działania takich układów.

W artykule rozważone zostaną problemy systemowe: najmniejszej „czarnej skrzynki" oraz najmniejszego systemu autonomicznego w sensie Mariana Mazura. Przedstawione będą również pewne konsekwencje biologiczne. Przy użyciu uogólnienia Mazurowskiego pojęcia autonomu analizie poddane będą proste ilościowe aspekty łączenia i optymalizacji działania takich układów. Następnie przedstawione zostaną podstawowe strategie energetyczne organizmów żywych, zapobiegające degeneracji ich materii: rozbudowa, transformacja struktury oraz odrzucanie zużytego tworzywa.

\footnotetext{
${ }^{1}$ Por. Marian MAzuR, Cybernetyka i charakter, PIW, Warszawa 1976, s. 163.
} 


\section{Zagadnienie minimalnego autonomu ${ }^{2}$}

\section{Podzial systemów na klasy}

Podział systemów na klasę systemów działaniowych (acting) i klasę systemów konfiguracyjnych (pattern) wprowadził Alfred Kuhn. ${ }^{3}$ Wyszczególniając podsystemy w systemie typu acting, mamy na uwadze funkcje przez nie wykonywane, wyszczególniając podsystemy typu pattern, mamy na uwadze układy fizycznie oddzielne, na które da się podzielić badany system.

Rozważania na temat systemów działaniowych pomagają w rozwiązywaniu problemów decyzyjnych (jak coś działa). Systemy typu pattern wprowadza się przy rozwiązywaniu problemów poznawczych (jakie coś jest).

Punktem wyjścia naszych rozważań będzie najprostszy system, mianowicie czarna skrzynka (black box).

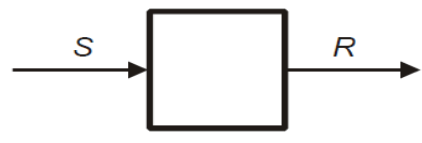

Rys. 1. Czarna skrzynka.

Przez $S$ (stimulus, bodziec) oznaczymy oddziaływanie wejściowe; przez $R$ oznaczymy oddziaływanie wyjściowe (reaction, reakcję). Jak widać z rysunku, aby uznać, że system istnieje, jego Obserwator (pisany z dużej litery, bo traktowany podmiotowo) powinien wykonać następujące czynności: (a) zmierzyć sygnał $S$ uznany za wejściowy; (b) zmierzyć sygnał $R$ uznany za wyjściowy; (c) porównać wielkość tych sygnałów; (d) podjąć jedną z następujących decyzji: (1) jeżeli $S>R$, to uznać, że system istnieje; (2) jeżeli $S=R$, to nie wiadomo, czy system istnieje; (3) jeżeli $S<R$, to Obserwator pomylił wejście z wyjściem (kierunek procesu). Można zresztą powiedzieć, że systemy tworzy Obserwator.

\footnotetext{
${ }^{2}$ Część I. jest poprawioną wersją opublikowanego już artykułu: Maciej WĘGRZYN, „Zagadnienie minimalnego autonomu", Problemy Genezy 2007, t. XV, nr 1-2 (215-216), s. 43-50.

${ }^{3}$ Por. Alfred Kunn, The Logic of Social Systems: A Unified, Deductive, System-Based Approach to Social Science, Jossey-Bass, San Francisco 1974.
} 


\section{Budowa najmniejszej „czarnej skrzynki”}

Budowę takiej „czarnej skrzynki” rozpatrzymy biorąc pod uwagę pewne właściwe fizyczne otoczenia. Jest to o tyle ważne, że nie zawsze w rozważaniach systemowych mówi się o otoczeniu układu, często pomijając je na schematach. Poza tym na ogół otoczenie traktuje się jako izotropowe (to jest jednakowe pod względem właściwości we wszystkich kierunkach). Tymczasem fizycy twierdzą, że materia ma strukturę ziarnistą, zaś każde działanie wymaga pewnego przepływu energii, który następuje od większego do mniejszego potencjału. Energia może być uwalniana tylko porcjami, nie zaś w sposób ciągły.

Pytanie, jakie postawił mój kolega, Adam Lech, brzmiało: jakie jest najmniejsze skupienie energii i materii, które może działać jak system?

Aby mogło zadziałać wyjście, musi wystąpić różnica potencjałów pomiędzy wyjściem a otoczeniem. Przyjmijmy, iż jest ona dodatnia i wynosi jedną porcję (ziarno, kwant) energomaterii na wyjściu systemu, czyli $R=1$. Ponieważ wielkość owego ziarna zależy od możliwości poznawczych Obserwatora, więc minimalna wielkość systemu jest rzeczą umowną — trzeba określić, jakie ziarna rozpatrujemy.

Aby mógł nastąpić przepływ energomaterii pomiędzy wejściem a wyjściem, wejście musi mieć potencjał wyższy od wyjścia, gdyż pewna część energii jest zużywana na potrzeby systemu:

a) Jeżeli przyjmiemy, że różnica potencjałów także wynosi 1, to potencjał wejściowy musi być w sumie wyższy o 2 od otoczenia. Przeto skupienie energomaterii może stanowić podstawę „,czarnej skrzynki”, o ile zawiera 2 ziarna energomaterii. Gdyby straty były wyższe i wynosiły 2 ziarna, to wyjście nie zadziała.

b) Jeżeli przyjmiemy, że straty są niższe niż 1 ziarno, to ziarno na wyjściu układu musi być mniejsze od ziarna na wejściu układu.

c) Ponieważ Obserwator też jest systemem, to odbiera sygnały o energii 2 ziaren. I tylko takie będą nośnikami informacji. Pozostałe nie spowodują zadziałania „czarnej skrzynki”. 
Wielkość strat energomaterii przypadająca na jednostkę masy Marian Mazur określił jako stratność systemu. ${ }^{4}$ Jak widać z powyższych rozważań, nie zależy ona od jego masy i wynosi $1 / 2$. Jest to maksymalna dopuszczalna wielkość stratności umożliwiająca identyfikację systemu — przy większej stratności można pomylić oddziaływania wyjściowe z oddziaływaniami wynikłymi ze strat.

Jeżeli nośnikami energii będą kwanty promieniowania, to obowiązywać będą następujące reguły łączenia „czarnych skrzynek” w sieć systemów:

a) Jeżeli straty energii są niewielkie, dużo poniżej kwantu absorbowanego przez wejście systemu, to na wyjściu mogą pojawić się dwa kwanty o niższej wartości energetycznej:

$$
E=h v_{0} \geq h v_{1} \geq h v_{2},
$$

gdzie $n$ to częstotliwość.

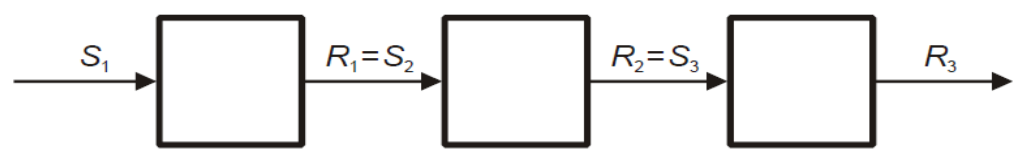

Rys. 2. Łączenie szeregowe „czarnych skrzynek”.

b) Jeżeli stratność wynosi 1/2, to można łączyć systemy tylko równolegle, mianowicie każdy następny musi być zasilany przez dwa poprzednie i działa wtedy jako mnożnik sygnałów.

c) Szereg można zawsze włączyć do równoległego działania, działa wtedy jako sumator sygnałów.

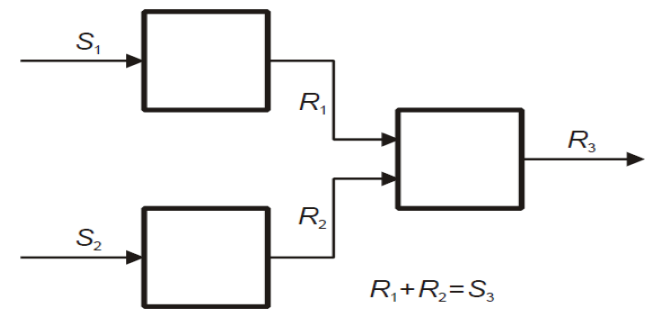

Rys. 3. Łączenie równoległe „czarnych skrzynek”.

${ }^{4}$ Por. MAzUR, Cybernetyka i charakter..., s. 203. 
d) Sieć kombinowana wymaga przetwarzania w ostatnim elemencie dwu kwantów o niższej częstotliwości w jeden o wyższej:

$$
2 h v_{1}=h v_{2} \text {. }
$$

Takie zjawisko też występuje. ${ }^{5}$ Połączenie dwu odcinków sieci, z których jeden działa jako szeregowy, a drugi jako równoległy, może nastąpić, gdy:

1. Połączenie ma charakter równoległy lub szeregowo-równoległy.

2. Dwa ziarna stanowiące sygnał z sieci szeregowej $(s)$ mają energię nieco wyższą niż jedno ziarno sieci równoległej $(p)$ :

$$
2 h v_{s}>h v_{p} \text {. }
$$

e) Sieć kombinowana ma dwa różne rodzaje częstotliwości wejściowej przy czym częstotliwość „,szeregowa” jest prawie dwukrotnie niższa niż częstotliwość „równoległa”.

$$
2 v_{s} \cong v_{p}
$$

Ilustracją takiego łączenia „czarnych skrzynek” jest działanie chlorofilu w procesie fotosyntezy. Mianowicie dwa fotony odczepiają dwa elektrony, które przenoszone są na coraz niższe poziomy energetyczne. Chlorofil wykazuje dwa pasma maksimum absorpcji - w fiolecie i w czerwieni. Do tej pory nie prowadzono badań celem wyjaśnienia, dlaczego akurat te pasma są absorbowane, bo dla zapewnienia zasilania wystarczyłoby jedno, ale jedno pasmo ogranicza możliwość budowania sieci logicznych — albo buduje się szeregowe, albo równoległe. Ponadto można udowodnić, że sygnał podwojony pojawia się trzy razy częściej niż pojedynczy, przez co sieć nastawiona na zasilanie dwoma ziarnami ma lepsze warunki do działania. ${ }^{6}$

\footnotetext{
${ }^{5}$ Por. Arkadiusz H. PIEKARA, Nowe oblicze optyki, PWN, Warszawa 1976, s. 213.

${ }^{6}$ Por. Henryk WiśnIEWSKI, Biologia z higieną i ochroną środowiska, AGMEN, Warszawa 1997, s. 74.
} 


\section{Struktura sieci przystosowanych do rozwiązywania zadań logicznych}

Przesyłanie sygnałów wymaga połączeń szeregowych, dodawanie (zbiorów) sygnałów - połączeń równoległych z sieci szeregowych, mnożenie (zbiorów) sygnałów - połączeń równoległych z sieci równoległych.

Mnożenie sygnałów (zbiorów), z których jeden powstał w wyniku dodawania, a drugi w wyniku mnożenia sygnałów (zbiorów), wymaga pracy na dwu częstotliwościach, z których pierwsza jest niecałe dwa razy niższa niż druga. Ze znanych mi opracowań teorii obwodów i logiki dla elektroników nie wynika, aby takie możliwości były rozpatrywane, chociaż mają one konsekwencje dla konstrukcji sieci systemowych. Można zbudować maszynę rozwiązującą konkretne zadanie logiczne składające się z dodawania i mnożenia sygnałów (zbiorów), jednak przy niepełnym zasileniu wejść maszyna ta będzie rozwiązywać zadanie inne od pierwotnego.

\section{Najmniejszy możliwy do zrealizowania autonom typu pattern}

Podamy teraz schemat funkcjonalny systemu autonomicznego, ${ }^{7}$ czyli systemu sterującego się „,we własnym interesie”, który w cybernetyce Mazura jest między innymi modelem organizmów żywych. *

\footnotetext{
${ }^{7}$ Zwanego też „układem samodzielnym” lub ,autonomem” (por. MAzur, Cybernetyka i charakter..., s. 145). Mazur zmieniał swoją terminologię, początkowo używał określenia „układ samodzielny" (por. Marian MAzUR, Cybernetyczna teoria układów samodzielnych, WN-T, Warszawa 1966).

* (Przyp. rec.) Receptor odpowiada narządom zmysłów, czyli receptorom w zwykłym rozumieniu. Alimentator pobiera energomaterię (pożywienie) z otoczenia, akumulator gromadzi zapasy energomaterialne, a efektor działa na otoczenie w celu jego lokalnej modyfikacji. Korelator jest podsystemem decyzyjnym, natomiast homeostat utrzymuje równowagę funkcjonalną systemu, wpływając na akumulator i korelator. Nazwy oddziaływań między homeostatem i korelatorem oraz sprzężeń w samym korelatorze zostały celowo wybrane przez Mazura zgodnie z terminologią psychologiczną.
} 


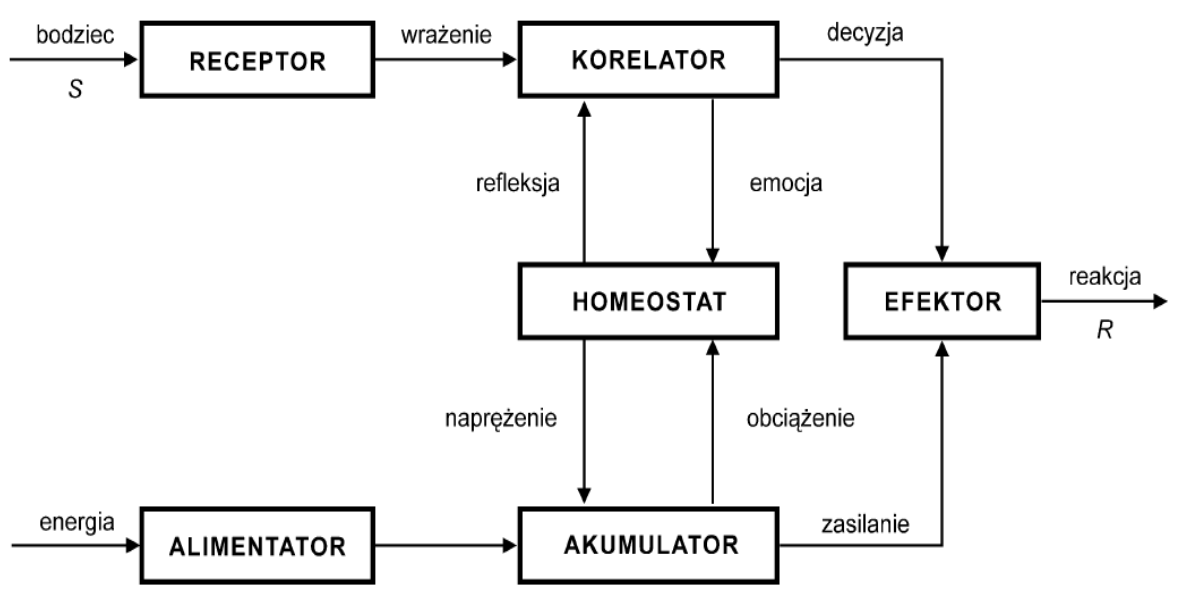

Rys. 4. Struktura systemu autonomicznego według Mariana Mazura.

Czy można zaprojektować autonom oszczędniej niż wedle schematu Mazurowskiego? Innymi słowy, czy wszystkie podukłady są istotnie niezbędne?

Najtrudniejszy do zrealizowania jest podsystem homeostatu. Wedle Adama Lecha ${ }^{8}$ układ połączeń w homeostacie wygląda następująco:

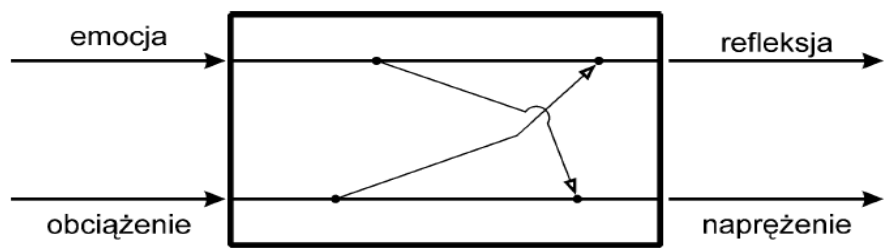

Rys. 5. Układ połączeń w homeostacie według Adama Lecha.

Wedle zasady Mazura, iż każda czynność wymaga zaznaczenia na schemacie odrębnego podsystemu, a przesyłanie sygnału jest $\mathrm{z}$ definicji ukierunkowane, zmodyfikujemy ten schemat, podsystemy rozdzielające sygnał oznaczając jako diody. Zgodnie z deklarowaną „oszczędnością” przyjmiemy, że podsystemy są

\footnotetext{
${ }^{8}$ Wykład Adama Lecha na VI Warszawskim Sympozjum Cybernetyki Polskiego Towarzystwa Cybernetycznego, listopad 1987 (nieopublikowany maszynopis Adama Lecha i Macieja Węgrzyna).
} 
właśnie najmniejszymi „,czarnymi skrzynkami”. Narysowanie ich jako diod wynika $\mathrm{z}$ tego, że przekazują sygnały tylko w jedną stronę, to jest od wejścia do wyjścia:

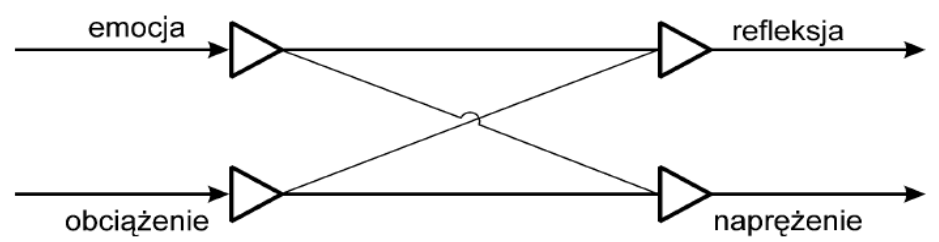

Rys. 6. Układ diodowy połączeń w homeostacie.

Schemat ten można zmienić, uwidaczniając strukturę zupełnie analogiczną do mostka elektrycznego:

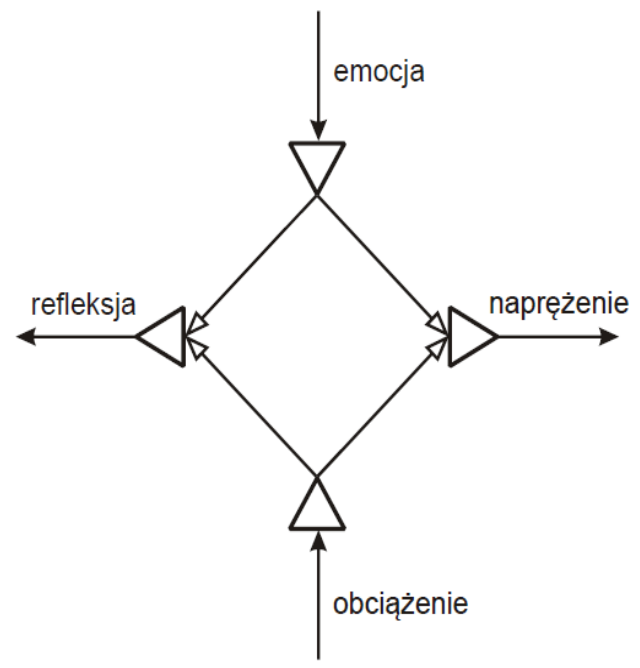

Rys. 7. Struktura mostkowa połączeń w homeostacie.

Kierując się zasadami Mazura, ustalmy, co też właściwie zaprojektowaliśmy. Homeostat ma za zadanie kompensować wpływy zewnętrzne. Jeżeli oddziaływanie na homeostat rośnie, to ma on je zmniejszać i odwrotnie. Ze schematu wynika, że gdy na jednym wejściu pojawią się dwa ziarna, to na każdym wyjściu pojawi się tylko jedno, a może zajść też sytuacja, że gdy na jednym wejściu będzie zero ziaren, to na wyjściu połączonym z nim szeregowo będzie 
jednak jedno ziarno. Wyjścia będą obciążone równomiernie, niezależnie od zasilania wejść!

Jak widać, powiodło się nam skonstruowanie homeostatu, ale to nie wszystkie funkcje, jakie ten układ spełnia. Korelator ma za zadanie gromadzić energię korelacyjną i przesyłać ją po ściśle określonych drogach przewodności. Nasz system nie robi nic innego. Problem tylko, że dróg przewodności jest mało ale to problem ilościowy, a nie sterowniczy. Według Mazura, w korelatorze po każdym przepływie powinna wzrastać przewodność, ale ten warunek jest o tyle trudny do uzasadnienia na poziomie mikro, że tutaj zmniejszenie oporności oznaczałoby utratę jakości tworzywa pozwalającej na koncentrowanie ładunku. Niemniej ten warunek da się spełnić, o ile na przykład przyjąć, że tworzywo ma już przewodność graniczną — wtedy nasz system niczego by się nie „uczył”, ale nie popadajmy w antropomorfizm. Jemu wystarczy to, co „wie”. Taki system w pewien sposób porządkuje otoczenie na swoich wyjściach, które są równomiernie obciążone niezależnie od obciążenia wejść systemu, a ponadto gdyby sygnał wejściowy miał charakter ciągły, to po przejściu przez taki autonom już ciągły nie będzie, bo zostanie rozdzielony na dwie połówki.

System nie musi mieć oddzielnego akumulatora, bo jego elementy mają jakąś minimalną pojemność. Sprawa receptora i alimentatora rozwiązuje się sama, zresztą z teorii automatyki wynika, że podzespoły połączone szeregowo można zastąpić jednym. Natomiast efektor może znajdować się z powodzeniem w otoczeniu. Sytuacja w efektorze nie wpływa na homeostat bezpośrednio, ale poprzez obserwację otoczenia, gdyż zgodnie z układem podsystemów i oddziaływań w systemie autonomicznym (rys. 4) nie ma połączenia pomiędzy efektorem i homeostatem. Mazur rysował granice otoczenia tak, że efektor mógł być poza systemem. ${ }^{9}$

Skoro systemy połączone szeregowo można uznać za jeden układ, to utwórzmy następującą strukturę, zsuwając diody ze schematu mostkowego tak, by refleksja i emocja wpływały i wypływały $\mathrm{z}$ jednego elementu, a naprężenie i obciążenie $-z$ drugiego. Elementy takiej struktury mają tę własność, że dzielą

\footnotetext{
${ }^{9}$ Por. MAzUR, Cybernetyka i charakter..., s. 145, rys. 9.1.
} 
sygnał wejściowy na dwie połowy i jedną przesyłają do sąsiada, a drugą działają na otoczenie.

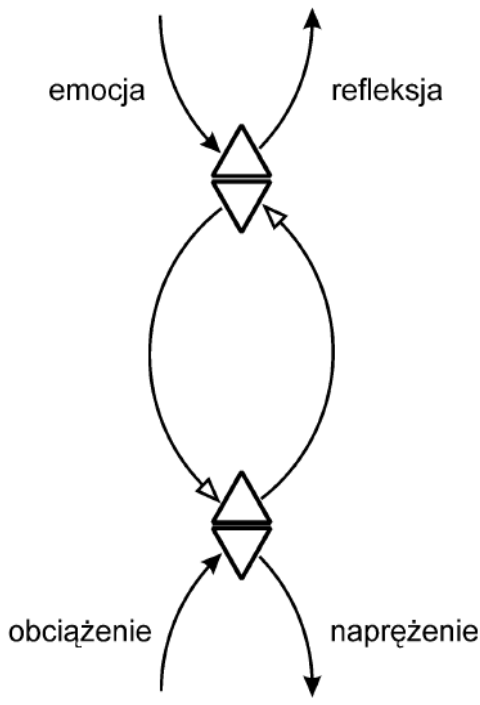

Rys. 8. Najmniejsza struktura odpowiadająca układowi autonomicznemu.

Jak widzimy, systemem autonomicznym może być taki system dwuelementowy, w którym każda część połowę swojego zasilania przekazuje drugiej połówce systemu (co jest ważne w małżeństwie). Zasada ta obowiązuje niezależnie od wielkości ziarna energomaterialnego. Mogą to być stosunki państwo-obywatel, w grupie koleżeńskiej i tak dalej. System utrzymuje się w równowadze przy zachowaniu „zasady połówkowej”, wedle której my zaspakajamy połowę potrzeb kontrahenta, on zaś połowę naszych. Wtedy żaden z partnerów nie dominuje i system trwa w równowadze.

\section{Poszukiwania najmniejszego istniejącego autonomu}

W świecie cząsteczek budowę analogiczną do podanej powyżej mają wiązania pomiędzy zasadami tworzącymi łańcuch DNA. ${ }^{10}$ Czy wynika z tego, że już DNA jest siecią najmniejszych systemów samodzielnych $\mathrm{w}$ rozumieniu

\footnotetext{
${ }^{10}$ Rudolf KLIMEK et al., Rak - nowotwory a choroby nowotworowe, Wydawnictwo Krakowskie, Kraków 2006, s. 107.
} 
Mazura? ${ }^{11}$ Podobnie do opisanej wyżej struktury działa wiązanie aromatyczne (na przykład w sześciokątnej cząsteczce benzenu). Wiązanie to niekiedy przedstawia się jako cykl ułożonych na przemian wiązań pojedynczych $\mathrm{C}-\mathrm{C}$ i podwójnych $\mathrm{C}=\mathrm{C}$, ale taki układ nie byłby trwały. W rzeczywistości związki aromatyczne zyskują trwałość dzięki temu, że elektrony niejako rozmywają się równomiernie po wszystkich połączeniach międzyatomowych (następuje ich „delokalizacja”). Ciekawe, że odkryte pod koniec dwudziestego wieku, tak na Ziemi, jak i w przestrzeni międzygwiezdnej, fullereny * zawierają wiązania podobne do aromatycznych. Czyżby fullereny ,pożerały” światło?

Badania nad sieciami minimalnych autonomów mogą mieć znaczenie przy opracowaniu nowych metod pozyskiwania substancji leczniczych (na przykład naprawiających łańcuchy DNA).

\section{Zapis matematyczny wlaściwości autonomu}

O ile zapis matematyczny sumowania zbiorów i iloczynu zbiorów jest ogólnie znany, to nie znam formalizacji połowienia zbioru. Odpowiedni formalizm pomógłby prześledzić prawidłowości, jakie rządzą elementami sieci. Wydaje mi się, że obecnie używane narzędzia do tworzenia tak zwanych sieci neuronowych — programów komputerowych zdolnych do samodoskonalenia się — nie wykorzystują prawidłowości rządzących najmniejszymi systemami autonomicznymi.

\footnotetext{
${ }^{11}$ Kwestia nie dotyczy tylko autonomów Mazurowskich, wiąże się bowiem z problemem elementarności w biologii (por. Marian WNUK, Geneza i rozwój idei elementarnej jednostki życia. W kierunku filozofii nanobiologii, Wydawnictwo KUL, Lublin 2013).

* (Przyp. rec.) Fullereny stanowią trzecią, obok diamentu i grafitu, główną odmianę alotropową węgla. Są to siatkowate struktury przypominające sfery, elipsoidy, wielościany, rurki lub kombinacje tych kształtów, złożone z parzystej liczby atomów węgla, od 20 do co najmniej setek. Często fullerenami nazywa się tylko struktury bryłowate, a rurkowate zwie się nanorurkami. Najbardziej znany jest sferoidalny buckminsterfulleren $\mathrm{C}_{60}$. Fullereny są pod względem reaktywności podobne do związków aromatycznych, ale nie występuje w nich całkowita delokalizacja elektronów, w związku z czym występują w nich dwa, a nie jeden rodzaj wiązań, jak na przykład w benzenie.
} 


\section{Optymalizacja w układach samodzielnych}

\section{Ocena skuteczności procesów optymalizacyjnych}

Jednym z celów cybernetyki jest wypracowanie ogólnej teorii sterowniczej układów żywych. ${ }^{12}$ Realizując ten cel, Marian Mazur wprowadził pojęcie układu samodzielnego ogólniejsze od pojęcia układu żywego. ${ }^{13}$ Warunkiem koniecznym do tego, aby dany układ samodzielny mógł przeżyć w danym środowisku (to jest zachować możliwości wpływu na otoczenie i sterowania samym sobą w celu uzyskania zasilania) zgodnie z założeniami teorii cybernetycznych, jest posiadanie w dyspozycji pewnej ilości mocy. Cybernetyka bowiem: „bada zjawiska ze względu na ich różnorodność - to aspekt informacyjny, oraz ze względu na ich intensywność - to aspekt energetyczny. Od ujęcia humanistycznego różni ją wprowadzenie obowiązku rozpatrywania wpływu posiadanej przez obiekt (lub będącej w jego dyspozycji) energii i możliwości jej użycia do wpływu na środowisko, zaś intensywność oddziaływania mierzy się mocą fizyczną". ${ }^{14}$ Przekazywanie informacji również wymaga dostarczenia energii: do wytworzenia oryginału informacji, zapisu tegoż, kodowania, przesyłu, odkodowania oraz odczytu i odtworzenia informacji w postaci obrazu. Jest to istotne ograniczenie możliwości działania wszystkich układów. ${ }^{15}$ Zgodnie z uwagami w części I. niniejszego artykułu zjawiska badane są za pomocą modeli, dla których punktem wyjścia jest opis funkcji, a nie fizyczna odrębność. Od fizykochemii odróżnia cybernetykę abstrahowanie od własności tworzywa, z jakiego są zbudowane rozpatrywane obiekty i badanie właściwości modeli zbudowanych według przyjętych założeń. Dlatego możliwe jest budowanie modeli komputerowych działających jako układy samodzielne i obserwowanie ich zachowań pod

\footnotetext{
${ }^{12}$ Por. np. Robert Piotrowski, „Filozoficzne założenia cybernetyki”, Peculiarity of Man 2012, nr 16, s. 144.

${ }^{13}$ Por. MAZUR, Cybernetyczna teoria układów samodzielnych..., s. 55-57.

${ }^{14}$ Por. Maciej WęGRZYN, „Cybernetyczne przyczyny powstawania konfliktów w ramach cywilizacji europejskiej", Peculiarity of Man 2012, nr 16, s. 151.

${ }^{15}$ Ogólnie wyraża to zasada energomaterialności (por. np. Pıотrowski „Filozoficzne założenia cybernetyki...", s. 141).
} 
wpływem zmieniających się bodźców zewnętrznych z modelowanego również środowiska. Wygoda w użytkowaniu takich modeli jest oczywista.

\section{Uklad samodzielny i jego równowaga funkcjonalna}

Zgodnie z tym, co powiedziano wyżej system autonomiczny (układ samodzielny) ${ }^{16}$ jest tworem wypełniającym następujące funkcje sterownicze: steruje sobą samym i zapobiega utracie zdolności sterowania sobą. Aby faktycznie tak było, każdy proces informacyjny (określający typ reakcji) oraz proces energetyczny (określający natężenie reakcji) musi sprzęgać ze sobą coś, co tą czy inną drogą utrzymuje równowagę funkcjonalną (homeostazę) systemu i co wchodzi w skład tego systemu — tym czymś jest homeostat.

Oczywiście każdy proces wymaga przepływu energii, ale w procesach informacyjnych jest to energia sterownicza, która służy do wskazania różnic między stanami fizycznymi, podczas gdy w procesach energetycznych jest to energia poświęcona na wykonanie pracy służącej do przeprowadzenia transformacji jednych stanów fizycznych w drugie. Stąd rozdział funkcji między odpowiednie podsystemy. Podział na podsystemy jest ponadto poddany rygorom ścisłej funkcjonalności - jeden podsystem spełnia tylko jedną funkcję, zaś do wypełnienia jednej funkcji służy zawsze tylko jeden podsystem. Relacja między zbiorem podsystemów i zbiorem funkcji jest „relacją doskonałą”. Między podsystemami występują sprzężenia proste i sprzężenia zwrotne. Na rys. 9 poniżej przedstawiono funkcje podsystemów i sprzężenia podsystemów w systemie autonomicznym, tworząc schemat przepływu mocy $\mathrm{i}$ informacji w systemie autonomicznym. Podsystemy charakteryzuje się dodatkowo przy pomocy reaktywności, jest to ilościowa miara sposobu transformowania bodźców. Reaktywność $r=+1$ oznacza wierne transformowanie, zaś $r=-1$ oznacza odwracanie oddziaływań. Akumulator i korelator mają $r=1$, homeostat zaś $r=-1$.

Zachowanie się systemu autonomicznego wynika ze sprzężeń zwrotnych między reakcjami a bodźcami. Korelator daje informacje o sposobach modyfikacji. Akumulator daje energię w pożądanej postaci. Efektor zasilany przez oba te podsystemy oddziałuje na otoczenie, aby zdobyć niezbędny stopień zasilania

\footnotetext{
${ }^{16}$ Por. MAZur, Cybernetyka i charakter..., s. 163.
} 
i potrzebne informacje. Homeostaza systemu autonomicznego polega na sprzężeniu zwrotnym pomiędzy korelatorem a homeostatem oraz akumulatorem a homeostatem: odwracanie oddziaływań ma przeciwdziałać zarówno nadmiarom, jak i niedomiarom w koncentracji energii w systemie autonomicznym, w zakresie czułości homeostatu.

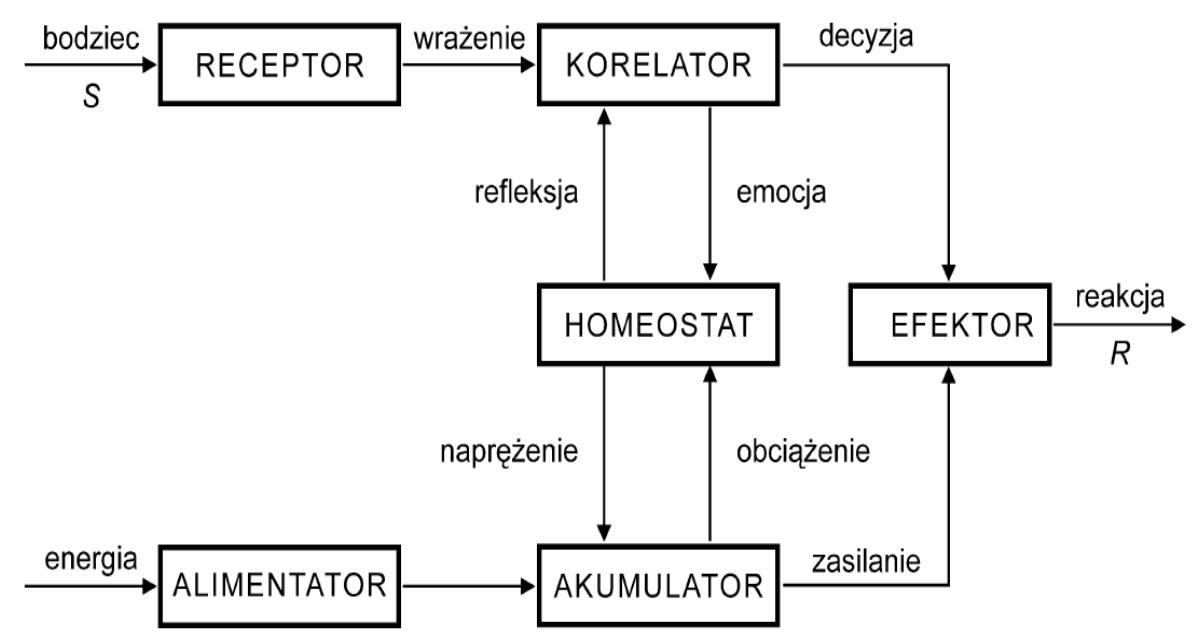

Rys. 9. Struktura systemu autonomicznego według Mariana Mazura.

Do celów dalszych rozważań uogólnimy ten schemat, nie rozpatrując struktury wewnętrznej, a jedynie „wejścia” i „wyjścia” systemu, oraz przyjmując następujące uogólnienia:

1. Wejścia systemu są dwu typów:

— energetycznego, pobierające zasilanie $S$ z otoczenia;

- informacyjnego, pobierające informacje $I \mathrm{z}$ otoczenia. Zasilanie $\mathrm{i}$ informacje są następnie wykorzystywane $\mathrm{w}$ procesie sterowania.

2. Wyjścia systemu są również dwu typów:

- wyjście energetyczne, dające realizację w formie bodźca energetycznego $R$ skierowanego na otoczenie; 
- wyjście informacyjne, dające zoptymalizowane informacje przydatne w sterowaniu $O$.

Po tych uogólnieniach efektor systemu autonomicznego, uprzednio traktowany jako podsystem, wyłączymy z systemu i będziemy go uważać za składnik otoczenia. Otrzymane w ten sposób uogólnienie Mazurowskiego systemu samodzielnego przedstawia się następująco: ${ }^{17}$

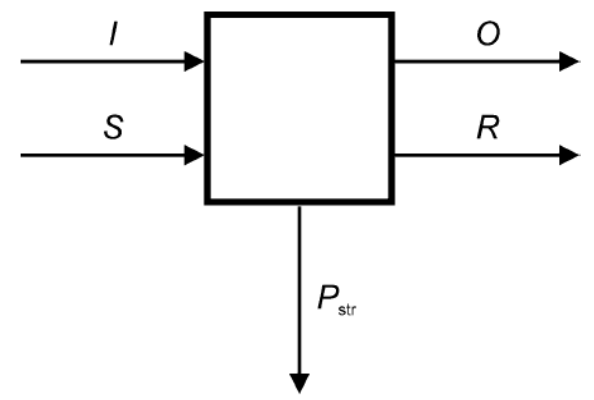

Rys. 10. Uogólnienie schematu systemu autonomicznego.

Liczenie informacji wpływających do systemu i wydawanych przezeń powoduje niedogodności pomiarowe z powodów opisanych przez Mazura, ${ }^{18}$ który dowiódł, że wzór Shannona dotyczy tylko informacji identyfikujących, a w sytuacjach sterowniczych mogą występować zarówno informacje identyfikujące, jak i opisujące. Drugim powodem jest hipoteza „zachowania informacji” wysunięta przez Jerzego Lechowskiego. ${ }^{19}$ Józef Kossecki wprowadził pojęcie wartości sterowniczej informacji, która jest tym większa, im lepiej dana informacja nadaje się do osiągnięcia celu sterowniczego. ${ }^{20}$

\footnotetext{
${ }^{17}$ Można by go nazwać systemem MAZUR, od akronimu wyrażenia „modyfikujący automat z uogólnionymi reakcjami”, ale to prowadziłoby do mylenia schematu oryginalnego z moim uogólnieniem.

${ }^{18}$ Por. Marian MAzur, Jakościowa teoria informacji, WN-T, Warszawa 1970.

${ }^{19}$ Por. Jerzy Lechowski, „Analiza możliwości modelowania elektrycznego przepływu informacji w środowisku", Postępy Cybernetyki 1983, t. 6, z. 3, s. 17-39.

${ }^{20}$ Por. Józef Kossecki, Cybernetyka społeczna, wyd. 2., PWN, Warszawa 1981, s. 213.
} 
Wprowadźmy następującą konwencję terminologiczną: użytecznościa sterownicza optymalizacji wykonywanej przez dany system sterowniczy będziemy nazywać różnicę między wartością informacji pobieranych przez system $(I)$ a wartością sterowniczą informacji zoptymalizowanych, wychodzących z wyjścia informacyjnego $(O)$.

We wspomnianej pracy Lechowski wskazał, że informacja nie może płynąć bez nośnika, a nośnikowi energomaterialnemu przypisał pewną graniczną ilość informacji. $Z$ tego wynika, że dopływ informacji jest również dopływem energomaterii, a sprawa podziału wejść i wyjść jest sprawą umownego uogólnienia, dotyczącą wewnętrznej organizacji systemu, a nie właściwości Obserwatora nie jest ważne, czy Obserwator uzna przejaw działania systemu za działanie wyjścia energetycznego czy informacyjnego, ważne jest, że rozróżnia to system sterowniczy.

\section{Skuteczność optymalizacji}

W jednostkowych odcinkach czasu pobieranie i wydawanie energii można mierzyć, używając mocy jako miernika oddziaływania.

Ze względu na potrzeby własne systemu część pobieranej mocy będzie rozpraszana jako moc stracona $P_{\text {str. }}$.

System nie może więc użyć całej mocy pobieranej $S$ na cele realizacyjne $R$ :

$$
S>R \text {. }
$$

Jednocześnie system przetwarza pobierane informacje o wartości $I$, uzyskując wzrost wartości sterowniczej, i wydaje je jako sposoby modyfikacji, czyli informacje zoptymalizowane o zwiększonej wartości $O$.

Warunkiem równowagi działania systemu (jego stabilności w otoczeniu) jest, by wzrost wartości sterowniczej informacji na wyjściu równoważył przez swoją skuteczność sterowniczą zmniejszenie mocy wydawanej, gdyż tylko wtedy moc pobierana wystarczy na potrzeby systemu. Równanie równowagi będzie miało postać równości iloczynów wartości wejściowych i wyjściowych:

$$
I S=O R \text {. }
$$


Współczynnikiem skuteczności optymalizacji $q$ będziemy nazywali stosunek wartości informacji wydawanych $O$ do uzyskiwanych $I: q=\frac{O}{I}$, wtedy (2) przyjmie postać:

$$
q=\frac{S}{R}
$$

Zależność ta jest o tyle cenna, że uwalnia od konieczności liczenia informacji i ocenienia ich wartości sterowniczej — skuteczność działania systemu sterowniczego oceniamy po wynikach w zakresie stosunku mocy pobieranej z otoczenia do mocy wydawanej w celach sterowniczych, aby uzyskać właśnie takie zasilanie. Mierzenie mocy jest poza tym o wiele łatwiejsze, łatwo też dokonać odpowiednich oszacowań.

Wprowadzając do równania równowagi mocy moc traconą $P_{\text {str }}$

$$
S=P_{t r}+R
$$

uzyskujemy wzór na $R$ :

$$
R=P_{\text {str }} \frac{1}{q-1} .
$$

Jak widać, współczynnik skuteczności optymalizacji powinien być większy od jedności, aby moc tracona była nieujemna — oznaczałoby to, że straty mocy na potrzeby własne pokrywane są z zapasów albo kosztem osłabienia koncentracji mocy w systemie. Przekształcając powyższy wzór, uzyskuje się:

$$
S=P_{s t r}\left(1+\frac{1}{q-1}\right) .
$$

Wzór ten oznacza, że przy nieoczekiwanym wzroście zasilania zewnętrznego i postulacie utrzymania określonego poziomu mocy zużywanej na potrzeby wewnętrzne systemu powinno się obniżyć współczynnik optymalizacji (stąd na przykład: świętowanie udanych polowań), aby nie zwiększać mocy przeznaczonej na użytek elementów systemu, którymi mogą być na przykład uczestnicy procesu produkcyjnego. 


\section{Użyteczność sterownicza optymalizacji}

Użytecznościa sterownicza optymalizacji $U$ nazwiemy różnicę wartości informacji O i I: $U=O-I$, natomiast wspótczynnikiem użyteczności nazwiemy stosunek użyteczności wartości sterowniczej informacji pobieranych: $u=\frac{U}{I}$, co po łatwych przekształceniach przyjmuje postać:

$$
u=q-1 \text {. }
$$

Współczynnik użyteczności jest miarą przyrostu wartości sterowniczej informacji wydawanych do wartości sterowniczej informacji pobieranych. Jest to miara wykorzystania pobieranych informacji, charakteryzująca zdolności systemu sterowniczego do wyszukiwania sobie źródeł wartościowych informacji.

Współczynnikiem postępu optymalizacji nazwiemy stosunek użyteczności sterowniczej do wartości sterowniczej informacji: $d=\frac{U}{O}$, co także łatwo przekształcić do postaci:

$$
d=\frac{q-1}{q} .
$$

Jest to miara wykorzystania do celów sterowniczych informacji przetworzonych (zoptymalizowanych) przez system. Współczynnik postępu optymalizacji jest oznaczeniem stopnia zawartości informacji sterowniczych wypracowanych przez system w całości wydawanych informacji, stopniem innowacyjności.

\section{Oszacowania}

Porównajmy współczynnik optymalizacji dla pracy „fizycznej” i „umysłowej”. Wydatek kaloryczny na dniówkę roboczą wynosi ${ }^{21}$ przy ciężkiej pracy „fizycznej” $4500 \mathrm{kcal}$ (12 godzin przy zasilaniu $7500 \mathrm{kcal} /$ dobę przy pomocy posiłków). Przybliżone wartości współczynników wynoszą:

\footnotetext{
${ }^{21}$ Por. Zbigniew JетHоN et al., Normy fizjologiczno-higieniczne w medycynie przemysłowej, PZWL, Warszawa 1982.
} 


$$
q=\frac{7500}{4500}=\frac{5}{3}, u=q-1=\frac{2}{3}, d=1-\frac{1}{q}=\frac{2}{5} .
$$

Dla pracy umysłowej przyjmujemy: całkowita moc zużyta na pracę 1250 $\mathrm{kcal} /$ dobę, całkowite zasilanie $2500 \mathrm{kcal} /$ dobę (mniejsze od średniej z rocznika statystycznego, gdzie podaje się $2870 \mathrm{kcal} /$ dobę), skąd:

$$
q=\frac{2500}{1250}=2, u=1, d=\frac{1}{2} .
$$

Jak widać, mimo przyjętych w przykładzie danych niekorzystnych dla pracy umysłowej (w rzeczywistości zużycie mocy jest mniejsze niż $1250 \mathrm{kcal}$ dziennie), a przy pracy fizycznej zasilanie jest mniejsze niż 7500 kcal dziennie, współczynniki skuteczności, użyteczności i postępu optymalizacyjnego są dla pracy umysłowej wyższe. Moc zużywana na potrzeby własne przy ,pracy fizycznej”: 7500 - 4500 = 3000 jest znaczna, ale dzięki większemu zasilaniu taki system ma teoretycznie dużo więcej mocy koordynacyjnej niż system wykonujący ,pracę umysłową”. Cała moc koordynacyjna zużywana na potrzeby własne systemu pracującego fizycznie jest wyższa niż cała moc dyspozycyjna systemu zajmującego się ,pracą umysłową”, jednak ,praca umysłowa” jest uważana za „lepszą”, bo ma lepszy współczynnik skuteczności, użyteczności i postępu optymalizacyjnego.

Postępu w przemyśle szuka się często na drodze zwiększania wydajności maszyn i ograniczania wysiłku, aby zmniejszyć ilość mocy wydawanej przy pracy. Jeżeli stanie się to w drodze przemian w „otoczeniu” to przy niezmienionym współczynniku skuteczności optymalizacji otrzyma się spadek zasilania zgodnie z iloczynem: $S=q R$. Dlatego próby przenoszenia pracowników niewykwalifikowanych do pracy przy skomplikowanych urządzeniach skutkują spadkiem produkcji. Sposobem zwiększenia zasilania całości jest raczej zwiększenie zasilania pracowników „umysłowych”, bo optymalizacja o wyższym współczynniku skuteczności daje proporcjonalnie wyższe przyrosty zasilania. Współczynnik $q$ nie jest jednak stały i może się zwiększyć na przykład przez przyuczenie do zawodu czy szkolenie. 


\section{Organizacja pracy zespołów systemów optymalizacyjnych}

Rozpatrzmy dwa sposoby organizacji systemów optymalizacyjnych:

- równoległy, w którym ta sama informacja jest przetwarzana przez niezależne systemy należące do organizacji;

- szeregowy, w którym informacja przetworzona przez jeden system jest następnie przetwarzana przez następny system.

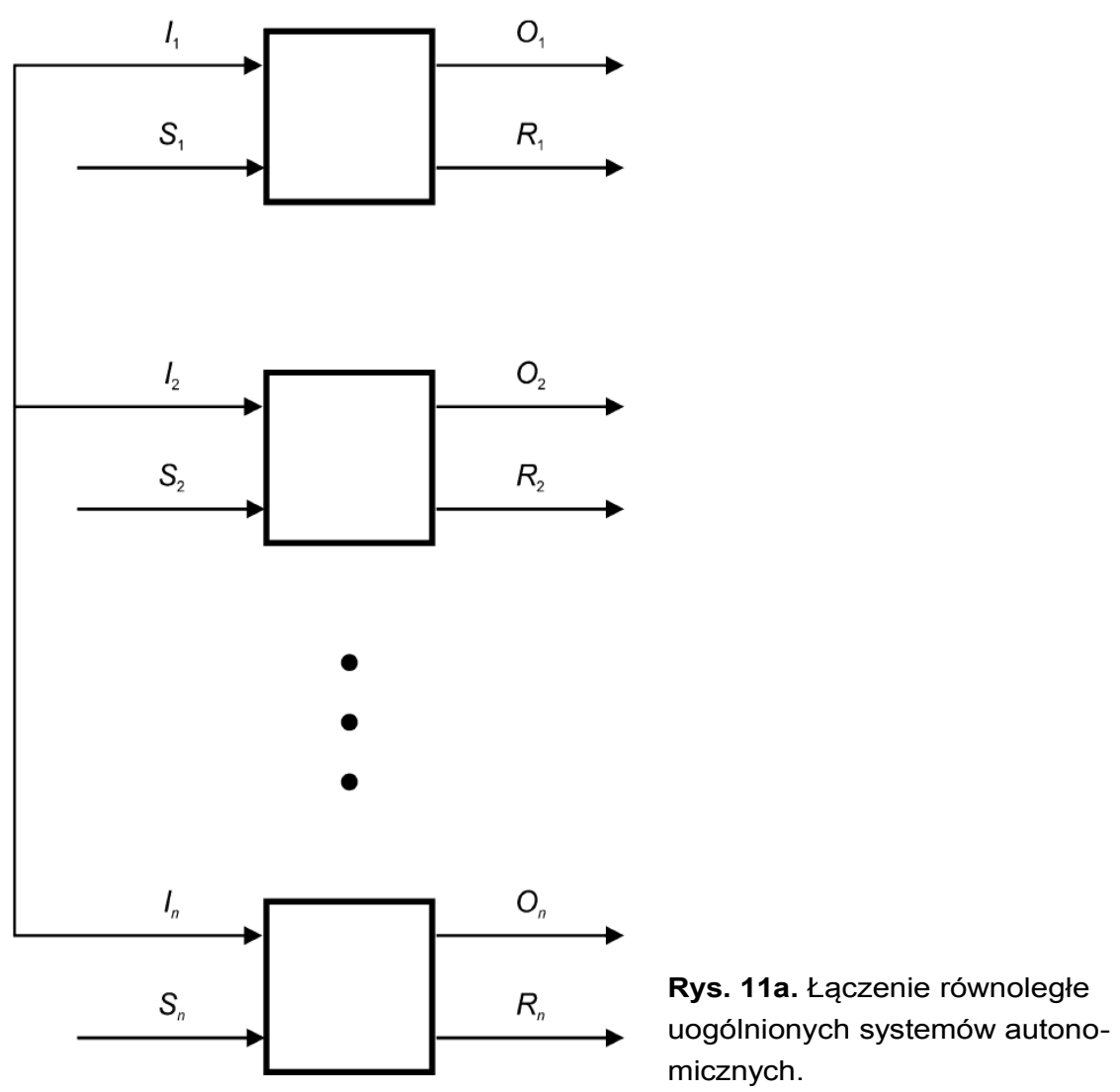



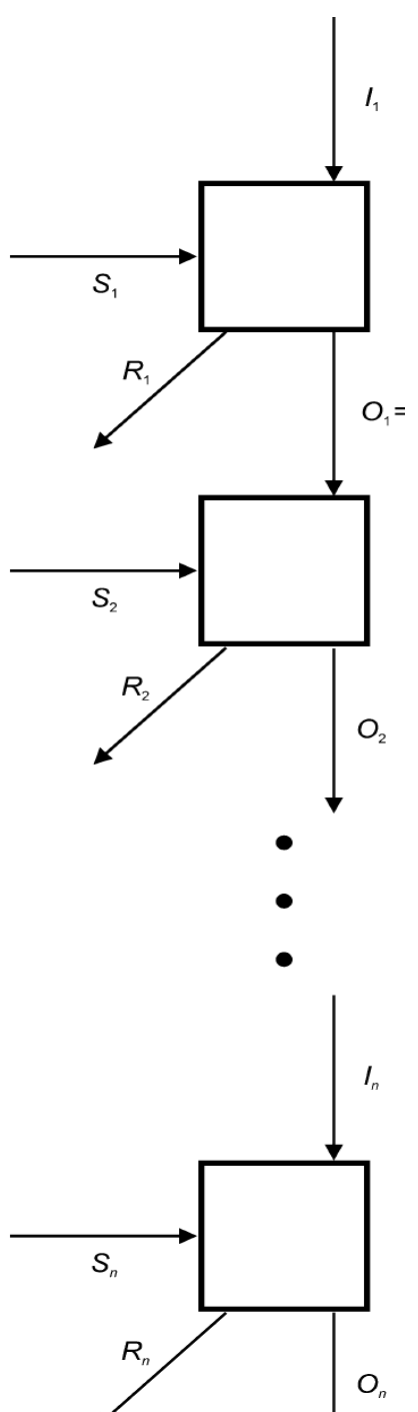

Rys. 11b. Łączenie szeregowe uogólnionych systemów autonomicznych. 
W systemie równoległym mamy:

$$
O_{1}=q_{1} I, O_{2}=q_{2} I, \ldots \text { zatem } O_{c}=\sum_{i} O_{i}=I \sum_{i} q_{i} \text {, a łączny współczynnik }
$$
optymalizacji równa się uśrednionemu $q$ :

$$
q_{c}=\frac{\sum_{i} S_{i}}{\sum_{i} R_{i}}=\frac{\sum_{i} O_{i}}{\sum_{i} I_{i}}=\frac{I \sum_{i} q_{i}}{n I}=\bar{q} ;
$$

współczynnik użyteczności

$$
u_{c}=\frac{U_{c}}{I_{c}}=\frac{O_{c}-I_{c}}{I_{c}}=\frac{I \sum_{i} q_{i}-n I}{n I}=\bar{q}-1 ;
$$

współczynnik postępu:

$$
d_{c}=\frac{U_{c}}{O_{c}}=\frac{O_{c}-I_{c}}{I_{c}}=\frac{I \sum_{i} q_{i}-n I}{I \sum_{i} q_{i}}=1-\frac{1}{\bar{q}} .
$$

Jak widać, przy równoległej pracy systemów optymalizacyjnych łączna wartość informacji $O_{c}$ jest duża, ale współczynniki użyteczności i postępu zależą tylko od skuteczności średniej, więc duże już nie są.

Przy pracy szeregowej system następny pobiera i przetwarza informację przetworzoną przez system poprzedni: $O_{1}=q_{1} I, O_{2}=q_{1} q_{2} I, \ldots$ zatem $O_{c}=O_{n}=\prod_{i} q_{i} I$. Jeżeli współczynniki skuteczności są jednakowe i równe $q$, to $O_{c}=q^{n} I$. Użyteczność sterownicza całości wyniesie:

$$
U_{c}=O_{c}-I_{c}=I\left(q^{n}-1\right)
$$

współczynnik skuteczności:

$$
q_{c}=\frac{O_{c}}{I}=q^{n}
$$


współczynnik użyteczności:

$$
u_{c}=\frac{U_{c}}{I_{c}}=q^{n}-1 .
$$

Dla $n$ dążącego do nieskończoności współczynnik użyteczności zrównuje się niemal ze współczynnikiem skuteczności. Współczynnik postępu wynosi:

$$
d_{c}=\frac{U_{c}}{O_{c}}=\frac{I\left(q^{n}-1\right)}{I q^{n}}=1-\frac{1}{q^{n}},
$$

co zbliża się do 1 dla dużych $n$.

Przy dużej ilości zorganizowanych w sposób szeregowy systemów optymalizacyjnych końcowa informacja jest tak „wysoko przetworzona”, że sprawia wrażenie „zupełnej” innowacji, czegoś, co ostatni system wytworzył „sam z siebie", ale podany schemat pokazuje, że jest to wynik pracy całego ciągu odpowiednio zorganizowanych systemów.

Jednostkowe współczynniki skuteczności mogą być niewielkie, a nawet któreś z nich mogły być mniejsze od jedności, a wynik będzie dużo lepszy niż przy łączeniu równoległym. Rzecz w tym, że nie wiadomo, które ze zorganizowanych w ten sposób systemów przetwarzają skuteczniej, a które mniej skutecznie, ale nie jest to problem optymalizacji przetwarzania przez dany system, lecz wynik ,,syndromu anankastycznego”, opisanego w jednym z opowiadań Lema. ${ }^{22}$

\section{Dynamizm optymalizacyjny}

Stosunek wartości informacyjnej $I$ na wejściu uogólnionego systemu autonomicznego do wielkości mocy zasilania $S$ nazwiemy dynamizmem informacyjnym środowiska:

$$
D_{s}=\frac{I}{S}=\frac{I}{q R},
$$

\footnotetext{
${ }^{22}$ Por. Stanisław Lem, „Ananke”, w: Stanisław Lem, Opowieści o pilocie Pirxie, wyd. 2. Czytelnik, Warszawa 1973, s. 421-490.
} 
natomiast stosunek wartości informacyjnej $O$ na wyjściu systemu do wielkości mocy roboczej $R$ nazwiemy dynamizmem informacyjnym roboczym uogólnionego systemu autonomicznego:

$$
D_{r}=\frac{O}{R}=\frac{q I}{R} .
$$

Dynamizm optymalizacyjny będzie różnicą tych dynamizmów:

$$
D_{m}=D_{s}-D_{r} \text {. }
$$

Po podstawieniach otrzymujemy:

$$
D_{m}=\frac{I}{S}-\frac{O}{R}=\frac{I}{q R}-\frac{q I}{R}=\frac{I\left(1-q^{2}\right)}{q r} .
$$

Adaptacja systemu nazwiemy stosunek dynamizmu systemu optymalizacyjnego do dynamizmu środowiska:

$$
A=\frac{D_{m}}{D_{s}}=\frac{I\left(1-q^{2}\right)}{q r} \cdot \frac{I}{q R}=\left(1-q^{2}\right) .
$$

Jak widać, adaptacja systemu wzrasta szybko przy wzroście współczynnika skuteczności optymalizacji. Kompetencja systemu będzie stosunek dynamizmu uogólnionego systemu autonomicznego do dynamizmu roboczego danego układu.

$$
C_{\text {comp }}=\frac{D_{m}}{D_{r}}=\frac{1}{q^{2}}-1 .
$$

Wysoki współczynnik skuteczności optymalizacji zapewnia wysoką kompetencję systemu. Z porównania współczynników adaptacji i kompetencji wynika:

$$
A=q^{2} C_{\text {comp }} \text {. }
$$

Adaptacja systemu zależy więc od jego kompetencji i współczynnika skuteczności przetwarzania informacji. 


\section{Zastosowanie praktyczne}

Porównując zawarte w artykule Adama Lecha ${ }^{23}$ dane dotyczące bilansu energetycznego człowieka i sosny, otrzymamy paradoksalne na pozór wyniki współczynników skuteczności optymalizacji, a co za tym idzie - pozostałych:

Tabela 1. Porównanie parametrów sterowniczych człowieka i sosny.

\begin{tabular}{|c|c|c|c|}
\hline & Człowiek & Sosna & $\begin{array}{c}\text { Wynik na ko- } \\
\text { rzyść sosny } \\
\text { (krotność) }\end{array}$ \\
\hline Moc całkowita $S[\mathrm{~J} / \mathrm{h}]$ & 8,8 & 10,1 & 1,1 \\
\hline $\begin{array}{l}\text { Suma mocy jałowej i } \\
\text { roboczej } R[\mathrm{~J} / \mathrm{h}]\end{array}$ & 8,0 & 2,0 & 0,25 \\
\hline $\begin{array}{l}\text { Współczynnik sku- } \\
\text { teczności } q \\
\end{array}$ & 1,1 & 5,05 & 4,6 \\
\hline $\begin{array}{l}\text { Współczynnik uży- } \\
\text { teczności } u\end{array}$ & 0,1 & 4,05 & 40,5 \\
\hline Adaptacja & $-0,21$ & $-24,2$ & 115,2 \\
\hline $\begin{array}{l}\text { Współczynnik postę- } \\
\text { pu } d\end{array}$ & 0,1 & 0,75 & 7,5 \\
\hline Kompetencja & $-0,18$ & $-0,96$ & 5,3 \\
\hline
\end{tabular}

Porównanie skuteczności działania optymalizatora sosny z optymalizatorem człowieka wypada wręcz żałośnie dla „pana stworzenia”. Ale to właśnie człowiek zwyciężył w walce o byt. Jak to zrobił, będąc tak źle zaadaptowany i tak niekompetentny w swoim własnym środowisku? Odpowiedź leży w rozważaniach o organizacji pracy systemów optymalizacyjnych: przecież ludzie, przekazując sobie wiedzę z pokolenia na pokolenie, działali jak system połączony szeregowo.

Ile pokoleń trzeba, abyśmy wyprzedzili sosnę w skuteczności optymalizacji? Gdy rodzice zaczęli uczyć swoje dzieci, zastosowali szeregowe łączenie systemów optymalizacyjnych, przez co współczynnik skuteczności $q_{\text {seq }}$ stał się równy:

$$
q_{\text {seq }}=q^{n}
$$

\footnotetext{
${ }^{23}$ Por. Adam Lech, „Charakter drzew”, Przegląd Techniczny 1985, nr 8 (4125), s. 25.
} 
Natomiast sosna poprzestaje na przekazaniu informacji genetycznej:

$$
q_{\text {par }}=\text { const. }
$$

Współczynniki skuteczności optymalizacji tych dwu systemów zrównały się dla liczby połączonych systemów optymalizacyjnych $n$, spełniającej:

$$
1,1^{n}=5,05
$$

w przypadku człowieka $n$ jest liczbą pokoleń. Z równania (25) wynika, że $n=18$; przyjmując około 30 lat na pokolenie, równa się to 540 latom. $Z$ punktu widzenia ewolucyjnej skali czasu, znaczy to prawie natychmiast.

Skąd taka doskonale zaadaptowana, kompetentna i skutecznie optymalizująca istota bierze tyle wartościowych informacji? Sprawa polega na czułości receptorów - dla sosny nośnikiem informacji są każde dwa fotony, gdyż one już stanowią zasilanie. Energia pochłaniana przy danej długości fali wynosi:

$$
E=\frac{h c}{\lambda},
$$

$c$ to prędkość światła, a $h$ to stała Plancka $\left(6,6 \cdot 10^{-34} \mathrm{~J}\right)$. Dla światła zielonego o długości fali $(\lambda=500 \mathrm{~nm})$ wynosi to $4 \cdot 10^{-19} \mathrm{~J}$. Dla dwóch fotonów będzie dwa razy więcej, czyli $8 \cdot 10^{-19} \mathrm{~J}$.

Przyjmijmy, że minimalna zauważalna porcja zasilania $E_{\min }$ dla człowieka, a więc użyteczna informacja, odpowiadać będzie spaleniu ziarnka maku o średnicy $d=0,3 \mathrm{~mm}$, ciężarze właściwym $\rho \approx 1,5 \mathrm{~g} / \mathrm{cm}^{3}$, przy cieple spalania $e=200 \cdot 10^{5} \mathrm{~J} / \mathrm{kg}$. Otrzymujemy $E_{\min } \approx 0,14 \mathrm{~J}$. Dlatego czułość receptorów sosny jest 10 do potęgi 18 razy wyższa od czułości na wejściu energetycznym człowieka.

Z doświadczeń Seliga Hechta i współpracowników ${ }^{24}$ wynika, że najmniejsza ilość energii, na jaką reaguje ludzkie oko, to od $2,1 \cdot 10^{-17} \mathrm{~J}$ do $5,7 \cdot 10^{-17} \mathrm{~J}$,odpowiada od 54 do 148 kwantów, z których jednak do komórek pręcików w warstwie zawierającej rodopsynę, barwnik pochłaniający światło, dochodzą 2 lub 3 kwanty. Jest to więc ten sam rząd wielkości, co dla chlorofilu. Należy pamię-

\footnotetext{
${ }^{24}$ Por. Selig Неснт, „Energy and Vision”, American Scientist 1944, vol. 32, no. 3, s. 159-177.
} 
tać, że rodopsyna nie zużywa padającego światła jako źródła energii, a wręcz przeciwnie, musi się od tej energii uwolnić, aby nie stracić swoich właściwości.

Jeżeli informacja nie jest związana bezpośrednio z zasilaniem, to powstaje sytuacja opisana $\mathrm{w}$ artykule Ryszarda Tadeusiewicza ${ }^{25}$ — korelator może się zablokować nadmiarem informacji i musi ulec podziałowi na dwie części, aby decyzje powstawały na podstawie „syntetycznych” informacji. To samo dzieje się w przypadku ludzkiego oka, ${ }^{26}$ rejestrującego do 2 milionów bitów na sekundę, z których do centralnych ośrodków sterowniczych dochodzi około 15 bit/s.

Tak rozbudowany korelator wymaga jednak większego zasilania w moc korelacyjną lub, w ogólniejszym przypadku, optymalizator w moc optymalizacyjną. Jak więc odbywa się zasilanie mocą poszczególnych podsystemów? Pokazuje to rys. 12 .

Jest to sytuacja najogólniejsza $\mathrm{z}$ punktu widzenia zasady funkcjonalności systemów, zgodnie z piątą zasadą metody systemowej Mazura, mianowicie zasadę rozłączności, ${ }^{27}$ wedle której każdy podsystem spełnia tylko jedną funkcję i każda funkcja jest wypełniana przez tylko jeden podsystem - między elementami zbioru funkcji, czyli działań określonego typu elementami zbioru podsystemów, zachodzą relacje jedno-jednoznaczne - w ten sposób wyraźnie rozdziela się funkcje systemu między podsystemy. Zwróćmy uwagę, że według tego założenia na pobranie informacji też potrzeba pewnej ilości mocy. Na przykładzie ludzkiego oka można uznać, że będzie to moc potrzebna na powrót rodopsyny do stanu wyjściowego. Podkreślał to już Marian Mazur, dzieląc komunikaty na czynne i bierne.

Nasz uogólniony system autonomiczny należy do klasy systemów „acting”, w której abstrahuje się od technicznych możliwości wypełniania danej funkcji, bowiem z punktu widzenia technicznego konstruowanie systemów z takich elementów, z których każdy wypełnia tylko jedną funkcję, jest po prostu rozrzutno-

\footnotetext{
${ }^{25}$ Por. Ryszard TADEusIEwICZ, „Badanie właściwości układów samodzielnych współdziałających ze stochastycznie zmiennym środowiskiem”, Postępy Cybernetyki 1979, t. 2, z. 4, s. 21-30.

${ }^{26}$ Por. Hecht, „Energy and Vision...”, s. 177.

${ }^{27}$ Por. Marian Mazur, „Pojęcie systemu i rygory jego stosowania”, Postępy Cybernetyki 1987, t. 10, z. 2, s. 25.
} 
ścią! Wiele wynalazków polega zresztą na łączeniu kilku funkcji przez jeden element. ${ }^{28}$

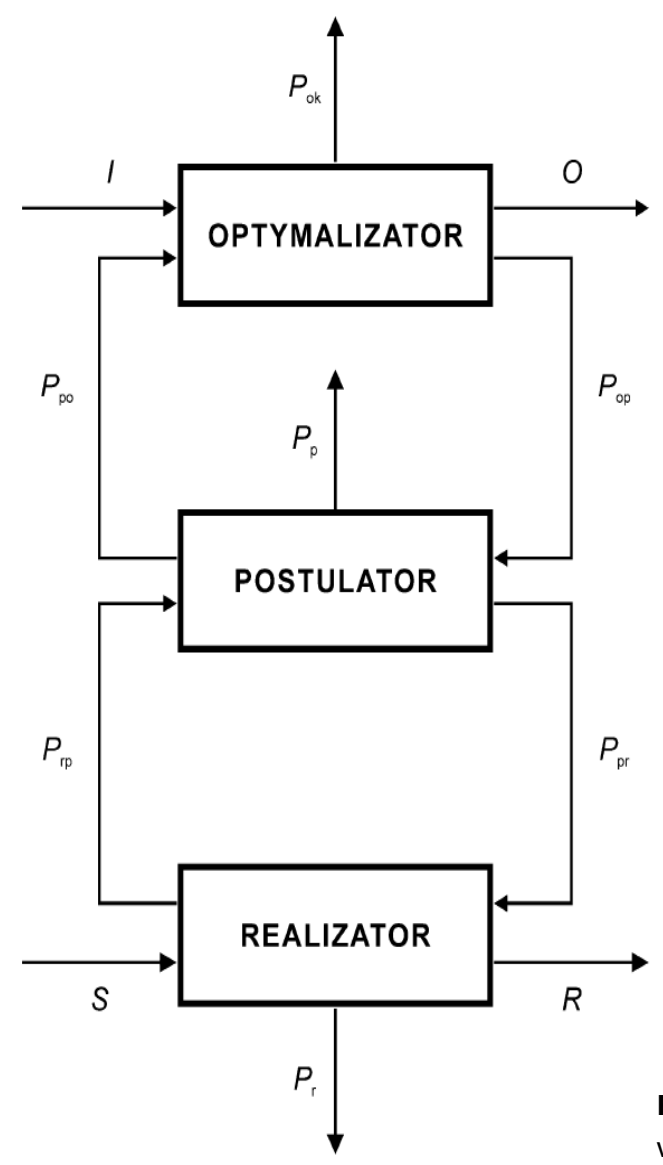

Rys. 12. Zasilanie podsystemów w systemie sterowniczym.

Wobec tego, że działanie optymalizatora jest uzależnione od zasilania pewną ilością mocy, można stwierdzić, że istnieje pewna zależność pomiędzy wartością zasilania a wartością współczynnika optymalizacji:

${ }^{28}$ Por. Henryk Altszuler, Algorytm wynalazku, przeł. Henryk Nowosad, wyd. 2., Wiedza Powszechna, Warszawa 1975. 
— zmniejszenie zasilania może oznaczać, że zabraknie mocy na pokrycie potrzeb związanych z którymś z poszczególnych rodzajów działań optymalizatora, i wtedy współczynnik skuteczności spada;

- zwiększenie zasilania może oznaczać, że dodatkowa ilość mocy zostanie skierowana na rozwinięcie któregoś z rodzajów działań, wtedy współczynnik skuteczności wzrośnie.

Analogiczne rozumowanie zostało przedstawione w odniesieniu do społeczeństwa, gdzie wzrost stopnia zorganizowania społeczeństwa uzależniono od wzrostu mocy koordynacyjnej. ${ }^{29}$

\section{Wniosek}

W przypadku, gdy współczynnik skuteczności, to jest optymalizacji systemu sterowniczego, jest zbyt niski, należy zwiększyć zasilanie podsystemu „Optymalizator". Jeżeli zwiększenie zasilania tego podsystemu jest niemożliwe, jedynym wyjściem jest zmiana organizacji elementów tego podsystemu z pracy równoległej na pracę szeregową, co można uczynić, o ile są to również uogólnione systemy autonomiczne, lecz za cenę wszystkich konsekwencji takiego postępowania. Podanie zależności matematycznych, opisujących efekty działań zmierzających do podwyższenia współczynnika, skuteczności przekracza ramy niniejszej pracy.

\section{Podstawowe strategie energetyczne organizmów}

\section{Sposoby na przeżycie}

System autonomiczny „lubi żyć”: to jest sterować się w otoczeniu tak, aby przetrwać jak najdłużej, ale aby żyć — trzeba dysponować pewną ilością mocy do oddziaływania na otoczenie i właściwą informacją o tym, jak należy zadziałać. Za mała ilość mocy może okazać się zagrożeniem dla uzyskania zasilania, za duża może zniszczyć środowisko. Niewłaściwa informacja o sytuacji może

\footnotetext{
${ }^{29}$ Por. KosSECKI, Cybernetyka spoleczna..., pkt. 5.4 „Koncentracja energii i informacji a organizacja społeczna", s. 210-220.
} 
spowodować, że całe działanie będzie nieskuteczne. Niestety, koncentracja mocy w jednostce masy maleje wskutek tendencji do wyrównywania się potencjałów i moc systemu może maleć. Ucierpieć przez to może również zdolność do przetwarzania informacji z braku mocy na potrzeby korelatora.

Według Mazura moc systemu można określić zgodnie ze wzorem: ${ }^{30}$

$$
P=n a c,
$$

gdzie: $P$ to moc całkowita systemu, $n-$ współczynnik proporcjonalności (moc jednostkowa przypadająca na jednostkę potencjału i jednostkę masy), a współczynnik jakości tworzywa (możliwość koncentracji mocy), $c$ - ilość (masa) tworzywa posiadającego możliwości koncentracji mocy.

Skutkiem procesów samowyrównawczych w tworzywie jego jakość samorzutnie spada, tym samym zmniejsza się współczynnik $a$, przez co ilość mocy będąca $\mathrm{w}$ dyspozycji również się zmniejsza. Aby temu zapobiec, trzeba stosować specjalne procedury.

\section{Sposoby podane przez Mariana Mazura — rozbudowa masy systemu}

Mazur opisał zwiększenie masy jako sposób na zachowanie (a nawet zwiększenie) ilości mocy dyspozycyjnej systemu. Według jego teorii to działanie homeostatu ${ }^{31}$ powoduje wzrost masy systemu jako przeciwdziałanie zakłóceniu równowagi funkcjonalnej przez zmniejszanie się ilości mocy dyspozycyjnej. Moc dyspozycyjna jest zużywana na potrzeby własne sytemu — jest to moc jałowa oznaczana $P_{o}$, oraz na oddziaływanie na środowisko - jest to moc dyspozycyjna oznaczona jako $P_{d}$, możemy to zapisać jako:

$$
P=P_{o}+P_{d} \text {. }
$$

Rozbudowa masy powoduje jednak wzrost zapotrzebowania na moc jałową proporcjonalnie do masy systemu (na przykład na utrzymanie temperatury ciała na poziomie największej skuteczności reakcji chemicznych). Współczynnik proporcjonalności $w$ zależy od rodzaju materii, z której zbudowany jest system:

$$
P_{o}=w c .
$$

\footnotetext{
${ }^{30}$ Por. Mazur, Cybernetyczna teoria układów samodzielnych..., s. 133.

${ }^{31}$ Por. MAzur, Cybernetyczna teoria układów samodzielnych..., s. 138-139.
} 
Wzrost mocy jałowej wydawanej na potrzeby własne systemu prowadzi w końcu do stanu, w którym cała moc dyspozycyjna zużywana jest na potrzeby własne i system traci możliwość oddziaływania na otoczenie i umiera ze starości. Marian Mazur podał dwie możliwości sterowania rozbudową masy systemu autonomicznego: rozbudowa równomierna zrównoważona, kiedy przyrost masy wyrównuje ubytki w mocy dyspozycyjnej, i rozbudowa niezrównoważona, kiedy przyrost masy przewyższa ubytki. Za najskuteczniejszy sposób sterowania się uznał taki sposób rozbudowy, że w początkowym okresie (w dzieciństwie) system szybko zyskuje masę, a potem wstrzymuje rozbudowę- wtedy maksimum mocy dyspozycyjnej jest wyższe niż w przypadku rozbudowy zrównoważonej.

Jednak eksperymenty komputerowe przeprowadzone przez zespół Tadeusiewicza ${ }^{32}$ wykazały, że modelowane systemy nigdy nie korzystały z możliwości ograniczenia rozbudowy (jakby były za młode i jako egzodynamiczne nie myślały o starości). Stąd wniosek, że powstrzymanie rozbudowy może mieć związek z otoczeniem sytemu, a właściwie z przestrzenią, w której system autonomiczny się rozwija. $Z$ braku przestrzeni systemy powstrzymują swoją rozbudowę. A więc to nie homeostat powstrzymuje rozbudowę systemu - zresztą według schematu homeostat nie ma takich możliwości: spadek zasilania powoduje wzrost aktywności korelatora, ale nie oznacza to zwiększania masy systemu. Tu pojawia się problem, które części ciała należą do systemu autonomicznego, a które należą do otoczenia, zawłaszczonego przez system autonomiczny. Do systemu autonomicznego należą te części ciała, które wykonują wyznaczone funkcje, a te, które funkcji nie wykonują, nie należą doń (na przykład zawartość przewodu pokarmowego). Również kości nie należą właściwie do systemu autonomicznego, stanowiąc rusztowanie i ochronę wrażliwych organów, w tym kości czaszki. I tu mamy odpowiedź - kostnienie czaszki oznacza zamknięcie możliwości rozwoju systemu autonomicznego. Gatunki, które ograniczają rozwój osobniczy, mają skostniałą czaszkę: są to ssaki i ptaki (i odwrotnie, te, które mają skostniałą czaszkę, ograniczają osobniczy rozwój masy ciała). Gatunki te również wykazują zachowania społeczne. Podobne skłonności mają owady, któ-

\footnotetext{
${ }^{32}$ Por. TAdeusiewicz, „Badanie właściwości układów samodzielnych...”, s. 28.
} 
rych larwy są wychowywane w zamkniętych przestrzeniach, na przykład mrówki i pszczoły.

Rozbudowa systemu daje także możliwości rozbudowy ilości tworzywa na usługi korelatora, gdyż ta sama substancja może wypełniać różne funkcje. Korelator powinien najpierw opanować sterowanie własnym systemem, a potem podjąc próby opanowania otoczenia — tak rozwijają się tendencje źródłowe. ${ }^{33}$ Przechodzą następnie w tendencje poznawcze, a potem zdobywcze, w końcu sprzymierzeńcze i wzajemne. Wiąże się to ze zwiększaniem poziomu charakteru systemu autonomicznego - może być skorelowana coraz większa ilość elementów, przeto wzrasta inteligencja całego systemu.

\section{Warunki informacyjne działania systemów autonomicznych}

Warunki informacyjne to potrzeba umiejętności i możliwości prawidłowego reagowania na zmiany w środowisku (więc trzeba zbierać informacje) na podstawie zapamiętanych danych. Pamięć bierna to drogi przewodności korelacyjnej — część dróg przewodności jest wrodzona, a część jest wypracowana. Zapamiętywanie wymaga utrwalania wzrostu przewodności - jest to mielinizacja substancji białej w mózgu. Nie ma możliwości takiego ustawienia w przestrzeni elementów korelacyjnych, aby odległości pomiędzy nimi były jednakowe, dlatego od czterech komórek tworzą się warunki do powstawania dróg wyróżnionych ze względu na bliskość elementów gromadzących potencjały korelacyjne (powstają talenty, preferencyjność), wyróżnienie dróg skojarzonych ze względu na większą powtarzalność (wiadomości o powtarzających się sytuacjach) lub na skojarzenia potencjałów korelacyjnych. Są to tendencje źródłowe, wynikające z samych właściwości organizmu, i nie zależą od sytuacji. Tendencje poznawcze są niezbędne dla odróżnienia sytuacji sprzyjających od niesprzyjających. Wzrost masy daje możliwość wzrostu ilości punktów koncentracji potencjałów i wzrostu możliwości tworzenia nowych dróg przewodności. Wzrasta wtedy poziom charakteru i są możliwe przejawy tak zwanych uczuć wyższych. Można wydedukować, że ograniczanie rozbudowy jest sprawą ewolucji. Badania Ta-

\footnotetext{
${ }^{33}$ Por. Marian MAzur, Zachowanie, maszynopis, §34; ftp://ftp.autonom.edu.pl/.
} 
deusiewicza ${ }^{34}$ wykazały, że większe szanse na przetrwanie mają organizmy mające wbudowane informacje dziedziczne, dużą impulsywność w pierwszej fazie istnienia, działające w środowisku zdeterminowanym, w którym można się sterować na strumień energii, i mające $\mathrm{w}$ dyspozycji pewną ilość mocy niezależną od otoczenia (opieka nad potomstwem). Tak sterujemy się my, ssaki naczelne.

\section{Przeksztalcanie struktury i przesunięcia potencjałów}

A jak to robią ,inni” — inne systemy autonomiczne? Można zastosować przekształcanie struktury i przesunięcie materii skupiającej potencjały energetyczne. Odbywa się to w ostatnim możliwym momencie — tak działają owady w fazie przepoczwarzania się (tworzenia imago z larwy). Motyle działają tak: po zgromadzeniu dużej ilości masy w stadium gąsienicy — przepoczwarzają się.

Tabela 1. Bilans mocy gąsienicy strzygoni choinówki. ${ }^{35}$

\begin{tabular}{|l|l|l|l|l|l|l|l|l|}
\hline Tygodnie & \multicolumn{1}{|c|}{1} & \multicolumn{1}{|c|}{2} & \multicolumn{1}{|c|}{3} & 4 & 5 & \multicolumn{1}{|c|}{6} & \multicolumn{1}{|c|}{7} & \multicolumn{1}{c|}{8} \\
\hline$c$ & 0,01 & 0,05 & 0,10 & 0,15 & 0,20 & 0,25 & 0,30 & 0,30 \\
\hline$a$ & 1,0 & 0,95 & 0,85 & 0,75 & 0,65 & 0,55 & 0,45 & 0,35 \\
\hline$n$ & 3,0 & 3,0 & 3,0 & 3,0 & 3,0 & 3,0 & 3,0 & 3,0 \\
\hline$w$ & 1,0 & 1,0 & 1,0 & 1,0 & 1,0 & 1,0 & 1,0 & 1,0 \\
\hline$P=n a c$ & 0,03 & 0,1425 & 0,255 & 0,3375 & 0,39 & 0,4125 & 0,405 & 0,315 \\
\hline$P_{o}=w c$ & 0,01 & 0,05 & 0,10 & 0,15 & 0,20 & 0,25 & 0,30 & 0,30 \\
\hline$P_{d}=P-P_{o}$ & 0,02 & 0,929 & 0,155 & 0,1875 & 0,19 & 0,1625 & 0,105 & 0,015 \\
\hline$z=P_{d} / c$ & 2,0 & 1,4 & 1,5 & 1,2 & 0,95 & 0,60 & 0,30 & 0,22 \\
\hline
\end{tabular}

Z pracy Adama Lecha ${ }^{36}$ wynika, że motyle strzygoni choinówki przepoczwarzają się w ósmym tygodniu egzystencji, w ostatnim możliwym momencie. Zespół Lecha dokonywał pomiarów masy gąsienic i obserwował możliwości

\footnotetext{
${ }^{34}$ Por. Tadeusiewicz, „Badanie właściwości układów samodzielnych...”, s. 29.

${ }^{35}$ Por. Adam Lech, „Regulacja liczebności strzygoni choinówki - model cybernetyczny”, Notatnik naukowy Instytutu Badawczego Leśnictwa 1991, nr 2, s. 5 [1-8].

${ }^{36}$ Por. LeCH, „Regulacja liczebności strzygoni choinówki...”.
} 
lotu motyla. Wyniki przedstawiono w tabelkach, jak niżej, przy czym współczynniki $a, n$ i $w$ podano iteracyjnie, aby zobrazować zmiany w mocy fizjologicznej i dyspozycyjnej tego organizmu.

Przepoczwarzanie następuje w momencie, kiedy moc dyspozycyjna się wyczerpuje i chociaż według kalendarza jest to czerwiec i najlepszy okres dla rozwoju organizmów, to egzystencja gąsienicy byłaby niemożliwa, gdyż nie miałaby siły się pożywiać.

Proces przepoczwarzania polega na przekształceniu zużytego tworzywa $z$ organizmu gąsienicy na chitynowy szkielet nowego organizmu - motyla. Przy odrzucaniu starego tworzywa odrzuca się też stare drogi przewodności mocy korelacyjnej i punkty koncentracji, motyle niczego nie pamiętają z życia gąsienicy. Przekształcanie struktury daje możliwość „drukowania” tendencji źródłowych: nowy rozkład materii korelacyjnej daje możliwość wytwarzania nowych talentów i nowych preferencji - instynkty motyli są niepodobne do instynktów gąsienic.

Tabela 2. Bilans mocy motyla strzygoni choinówki. ${ }^{37}$

\begin{tabular}{|l|l|l|l|l|l|l|l|l|}
\hline Tygodnie & \multicolumn{1}{|c|}{1} & \multicolumn{1}{|c|}{2} & \multicolumn{1}{c|}{3} & \multicolumn{1}{c|}{4} & \multicolumn{1}{c|}{5} & \multicolumn{1}{c|}{6} & \multicolumn{1}{c|}{7} & \multicolumn{1}{c|}{8} \\
\hline Masa $c$ & 0,30 & 0,30 & 0,30 & 0,30 & 0,30 & 0,30 & 0,30 & 0,30 \\
\hline$a$ & 0,6 & 0,58 & 0,56 & 0,54 & 0,52 & 0,50 & 0,48 & 0,46 \\
\hline$n$ & 2,0 & 2,0 & 2,0 & 2,0 & 2,0 & 2,0 & 2,0 & 2,0 \\
\hline$w$ & 1,0 & 1,0 & 1,0 & 1,0 & 1,0 & 1,0 & 1,0 & 1,0 \\
\hline$P=n a c$ & 0,36 & 0,348 & 0,336 & 0,324 & 0,312 & 0,30 & 0,22 & 0,276 \\
\hline$P_{o}=w c$ & 0,30 & 0,30 & 0,30 & 0,30 & 0,30 & 0,30 & 0,30 & 0,30 \\
\hline$P_{d}=P-P_{o}$ & 0,060 & 0,048 & 0,036 & 0,024 & 0,012 & 0,00 & & \\
\hline$z=P_{d} / c$ & 0,20 & 0,16 & 0,12 & 0,08 & 0,04 & 0,00 & & \\
\hline
\end{tabular}

Najwyższe wartości mocy dyspozycyjnej występują w pierwszych tygodniach życia i wtedy motyle dokonują aktów prokreacji. Po złożeniu jaj lot motyli staje się chybotliwy, a w 6 . tygodniu motyle zamierają wczepione w igliwie.

\footnotetext{
${ }^{37}$ LeCH, „Regulacja liczebności strzygoni choinówki...”, s. 5.
} 
Najciekawszy wynik tych obserwacji to fakt, że moc dyspozycyjna w pierwszym tygodniu $-P=0,36$ - jest większa niż moc dyspozycyjna gąsienicy w jej ostatnich tygodniach egzystencji, kiedy $P=0,315$.

Być może rozdzielanie masy systemu „poczwarka” przebiega tak, że moc systemu „motyl” skoncentrowana jest w nieco innym tworzywie niż w systemie „gąsienica”. Brak dostępnych dla nas danych na ten temat uniemożliwia wypowiadanie się, chociaż perspektywy badań są kuszące — odzyskanie młodości.

\section{Odrzucanie zużytego tworzywa}

Przeanalizujemy jeszcze inny sposób na zachowanie koncentracji mocy ten sposób stosują drzewa, ${ }^{38}$ odrzucając zużyte części, tworząc $\mathrm{z}$ nich pień i korę, zrzucając zużyte licie i igły i produkując nowe. Tak działają drzewa, odrzucając zużyte komórki łyka w pień i w korę.

Taki typ utrzymywania wysokiej koncentracji mocy mają także niektóre organizacje społeczne - na przykład armia poborowa co roku odsyła rezerwistów i przyjmuje rekrutów, a w ten sposób zawsze jest gotowa do pokazowych działań jako skupisko egzostatyków. Dlatego drzewa nie pamiętają wydarzeń z lat poprzednich, chociaż są doskonale przystosowane do środowiska (za to są nietolerancyjne i niepodatne ${ }^{39}$ ).

Adam Lech określił ten typ działania następująco:

Do rozstrzygnięcia przez fizjologów pozostała sprawa, czy rozbudowa drzew równoważy stratę potencjałów, czy jest to sytuacja statyzmu, czy też nie, a jeśli nie równoważy, to czy jest to nadmiar masy, czy niedobór? [...] ilość masy, jaką wytwarza sosna pospolita, z wielkim nadmiarem przewyższa straty energii wynikające ze zmniejszenia się różnic potencjałów - egzodynamizm. Istotny ten wniosek, że kierunek przemian energetycznych zachodzących w naszej sośnie zawiera się w sytuacji egzodynamicznej, obfituje w interesujące dla przyrodników konsekwencje.

\footnotetext{
${ }^{38}$ Por. LeCH, „Charakter drzew...”, s. 24-26.

${ }^{39}$ Tolerancja to stosunek mocy jałowej do mocy całkowitej, zaś podatność to stosunek mocy roboczej do mocy całkowitej. Współczynniki te razem określają szerokość charakteru systemu autonomicznego.
} 
Sosna, a sądzić można, że drzewa w ogóle, jest systemem przetwarzającym ilości energii wielokrotnie większe niż inne niezielone organizmy. Zanikanie różnic potencjałów zachodzi w stopniu bardzo nieznacznym, kilkadziesiąt razy wolniej niż u człowieka. To dlatego drzewa żyją tak długo. ${ }^{40}$

Przetwarzanie wielkich ilości energii w organizmie sosny byłoby dla niej niebezpieczne, gdyby nie umiejętność pozbywania się tych nadmiarów, gdyby nie funkcjonowanie homeostatu. Dzięki ujemnemu sprzężeniu zwrotnemu z akumulatorem i korelatorem homeostat pełni te dwie z pozoru sprzeczne ze sobą funkcje zapobiegania zmniejszaniu się ilości energii i uwalniania z nadmiarów.

Z oddanych przez drzewa nadmiarów energii korzystają inne organizmy. I to przy każdym oddechu! Chodzi tu bowiem właśnie o tlen, którego produkcja przez rośliny zielone możliwa jest w obecności dużych energii. A że drzewa mają jej za dużo, jak na własne potrzeby, chętnie i hojnie ją rozpraszają. [...] Drzewa jednak rosną całe swoje życie i przez cały czas znajdują się w korzystnej dla nas sytuacji egzodynamizmu.

Są natomiast mało odporne. Zmuszanie ich np. do rośnięcia w warunkach zanieczyszczonego środowiska kończy się ich śmiercią. Mając wyliczone energetyczne parametry charakteru dla drzew, nikt nie mógłby postawić absolutnie fantastycznej hipotezy o wyhodowaniu drzew odpornych na zanieczyszczenie. Taką myśl cybernetyk może i powinien wpierw zweryfikować, zanim ktoś zadecyduje, aby wydać pieniądze na próbne eksperymenty prowadzone metodą prób i błędów, w skali kraju czy kontynentu. ${ }^{41}$

Adam Lech określił charakter sosny jako bardzo wąski: tolerancja i podatność razem wynoszą 0,20 , co oznacza, że tylko 20-procentowa zmiana warunków środowiska jest tolerowana, dlatego zmiany w środowisku są zabójcze dla lasu. Lasy rosną na odpowiednich dla siebie obszarach i na przykład zalesianie stepów skazane jest na niepowodzenie. Również pokładanie nadziei we współpracę pomiędzy poszczególnymi drzewami jest nieuzasadnione - tak silny egzodynamizm uniemożliwia współpracę pomiędzy osobnikami. To, że z układu słojów drewna my możemy wyciągać daleko idące wnioski, nie oznacza, że drzewa też mają taką możliwość — brak jest dróg przewodności korelacyjnej pomiędzy „starym” a nowym tworzywem.

\footnotetext{
${ }^{40}$ Drzewa żyją aż do wyczerpania zapasów pożywienia w glebie.

${ }^{41}$ LeCH, „Charakter drzew...”, s. 25-26.
} 


\section{Zakończenie}

Po raz kolejny natrafiamy na przykład klasy systemów występujących jakby na zasadzie „albo jest, albo go nie ma”. W każdym razie wytyczenie odpowiednich dróg ewolucyjnych wydaje się niełatwe, chociaż pochopne byłoby upatrywanie tu aż dowodu na kreacjonizm. Nasze ustalenia wskazują ponadto na potrzebę dalszych badań nad procesami dotąd słabo zbadanymi z systemowego punktu widzenia, jak na przykład przepoczwarzanie się motyli. Takie organizmy jak owady i drzewa mają sposób na życie odmienny od rozważanego przez Mazura, choć mieszczący się w ramach jego doktryny. Mianowicie u ssaków, w tym u ludzi, przeciętna wartość dynamizmu charakteru odpowiada statyzmowi, natomiast przeciętny insekt czy drzewo okazuje się ezgodynamikiem.

Maciej Wegrzyn

\section{Modeling of Autonomous Systems and Optimization of Their Survival Strategies}

\section{Summary}

The problems of: a minimal „black box” and a minimal autonomous system (a concept proposed by Marian Mazur) are considered. Some biological implications are considered, too. A generalization of the autonomous system is used to present simple quantitative aspects of joining and optimization of functioning of such systems. Basic energetic strategies employed by organisms to prevent degeneration of their bodies are listed: extension, transformation of structure, rejecting worn out body parts.

Keywords: autonomous system, model-building, optimization, survival strategy.

Slowa kluczowe: system autonomiczny, modelowanie, optymalizacja, strategia zapewniająca przetrwanie. 